\title{
Comparative Evaluation of Calcium, Magnesium, Copper and Zinc Removal by Wood Ash, Sodium Carbonate and Sodium Hydrogen Phosphate
}

\author{
Lovell Agwaramgbo*, Jailen Doyle, Corneisja Harrison, Honour Williams \\ Chemistry Department, Dillard University, New Orleans, USA \\ Email: *lagwaramgbo@dillard.edu
}

How to cite this paper: Agwaramgbo, L., Doyle, J., Harrison, C. and Williams, H. (2021) Comparative Evaluation of Calcium, Magnesium, Copper and Zinc Removal by Wood Ash, Sodium Carbonate and Sodium Hydrogen Phosphate. Journal of Environmental Protection, 12, 454-461.

https://doi.org/10.4236/jep.2021.127028

Received: June 6, 2021

Accepted: July 4, 2021

Published: July 7, 2021

Copyright $\odot 2021$ by author(s) and Scientific Research Publishing Inc. This work is licensed under the Creative Commons Attribution International License (CC BY 4.0).

http://creativecommons.org/licenses/by/4.0/

\begin{abstract}
Remediation via adsorption process has been proven to be one of the best water treatment technologies globally. Many adsorbents, including agricultural wastes, have been considered for the removal of a variety of pollutants from water. However, most of the studies reported in the literature used metal concentrations below $1000 \mathrm{ppm}$. It is also known that initial metal concentrations in polluted aqueous solutions, as well as metal and adsorbent type, are some of the factors that affect metal removal. Therefore, this project examined the remediation of water contaminated by $1000 \mathrm{ppm}$ of lead, zinc, copper, magnesium, and calcium ions using wood ash, sodium hydrogen phosphate (dibasic), and sodium carbonate (dibasic). Comparative analysis of the results showed the order of order of metal removal by the adsorbents as: dibasic phosphate $(\mathrm{Ca}>\mathrm{Cu}>\mathrm{Pb}>\mathrm{Zn}>\mathrm{Mg})$; dibasic Carbonate $(\mathrm{Pb} \sim \mathrm{Ca}>$ $\mathrm{Zn}>\mathrm{Cu}>\mathrm{Mg})$; Wood ash $(\mathrm{Mg}>\mathrm{Cu}>\mathrm{Zn}>\mathrm{Pb}>\mathrm{Ca})$. These results suggest that metal and adsorbent type as well as the inherent chemical properties of these metal cations may contribute to the varying binding affinity of the metals to the adsorbent ligand(s) and thus, affect the extent of metal removal. It is equally worthy to note that wood ash more effectively removed hardness metals ( $\mathrm{Mg}$ and $\mathrm{Ca}$ ) from water than the inorganic phosphate and carbonate ions.
\end{abstract}

\section{Keywords}

Phytoremediation, Metal Adsorption, Water Hardness, Heavy Metal Contamination 


\section{Background}

Metals, especially heavy metals are distributed in the environment through natural, industrialization and anthropogenic activities. They are not degradable; thus, they persist in the environment [1]. Methods for metal removal from contaminated water include phytoremediation [2] [3] [4], electrodeposition and extraction [5]. However, phytoremediation has some drawbacks such as root length and accumulation capacity while electrodeposition is expensive and not meant for average citizens. Thus, researchers became interested in the use of agricultural waste as a potential method to remove heavy metals from contaminated water [6] [7] [8] [9]. We have previously reported the use of inorganic salts to remove lead from contaminated water [10]. However, such salts have not been used for Zinc, Copper, Calcium, and Magnesium removal from contaminated aqueous solutions. Although zinc, copper, calcium and magnesium are micronutrients required in small concentrations for human body, however, in higher concentrations they are toxic for living organisms and also for the environment [11]. The exposure to and contamination by these metals emanate from natural, industrial, and anthropogenic activities. Excess calcium in the body causes hypercalcemia, a condition in which the calcium level in the blood is above normal. Too much calcium in the blood can weaken the bones, create kidney stones, and interfere with how the heart and brain work. Hard water interferes with almost every cleaning task from laundering and dishwashing to bathing and personal grooming. Excess copper in the body can cause neurotoxicity, liver toxicity, and jaundice, liver failure, lung cancer and many other adverse ailments [12]-[18]. Excess zinc can have harmful and fatal effects on human health. [19] [20] [21]. Lead contamination has been a major global problem perpetuated by human activities. Historically, lead pollution results from a variety of human activities such as past practices of lead-related industrial activities by battery, paint, mining, ammunition, plumbing pipe, oil and petrochemical industries, agricultural fertilizer, insecticide, and pesticide. Lead contamination of water above permissible levels can cause elevated blood lead levels [22] [23] [24], spontaneous abortion [25], infant mortality [26], fetal death and reduction in birth rates [27]. The potential exposure of hazardous lead to citizens is widely exacerbated in rural areas due to the lack of water regulations and treatment [28] [29]. The lack of clean water for human consumption and activities will pose a major challenge globally if water management, pollution control, and regulations are not enacted and enforced. Therefore, this project reported here in this paper examines comparatively the removal ability of $\mathrm{Ca}, \mathrm{Mg}, \mathrm{Cu}, \mathrm{Zn}$, and $\mathrm{Pb}$ by wood ash and inorganic sodium carbonate and sodium hydrogen phosphate. Additionally, the efficiency of metal removal by $\mathrm{PO}_{4}^{3-}$ and $\mathrm{HPO}_{4}^{2-}$ was compared.

\section{Materials and Methods}

A standard solution of 1000 ppm of Ca (II), $\mathrm{Mg}$ (II), Cu (II), Zn (II) and Pb (II) ions were prepared using the corresponding salts, respectively by dissolving 
equivalent amounts in $1000 \mathrm{ml}$ of solution. Triplicate samples of $40 \mathrm{ml}$ of the metal solutions prepared above were placed in separate centrifuge tubes. Then, each of the triplicate samples were treated with 5 grams of each of the adsorbent substrates (wood ash, $\mathrm{Na}_{2} \mathrm{HPO}_{4}$ and $\mathrm{Na}_{2} \mathrm{CO}_{3}$ ). Each sample was vortexed to mix, and agitated for 24 hours at room temperature. The samples were centrifuged, and the supernatant from each treated sample was analyzed for residual metal ion concentration.

\section{Results}

Figure 1 shows residual calcium, copper, zinc, lead, and magnesium ion concentrations after treatment with the adsorbents compared to the control samples. There is a varying amount of residual metal across all adsorbents. The results in Table 1 showed the effectiveness of wood ash in removing metals, especially magnesium from their respective contaminated water samples. Phosphate and carbonate adsorbents were less effective in removing magnesium from the contaminated water but they interestingly removed almost all the calcium, zinc, copper, and lead ions in the solutions.

The results showed that on average, each of the adsorbents removed more than $90 \%$ of each metal from the solution except magnesium. The order of percent metal removal by the adsorbents is: for phosphate (calcium > copper >

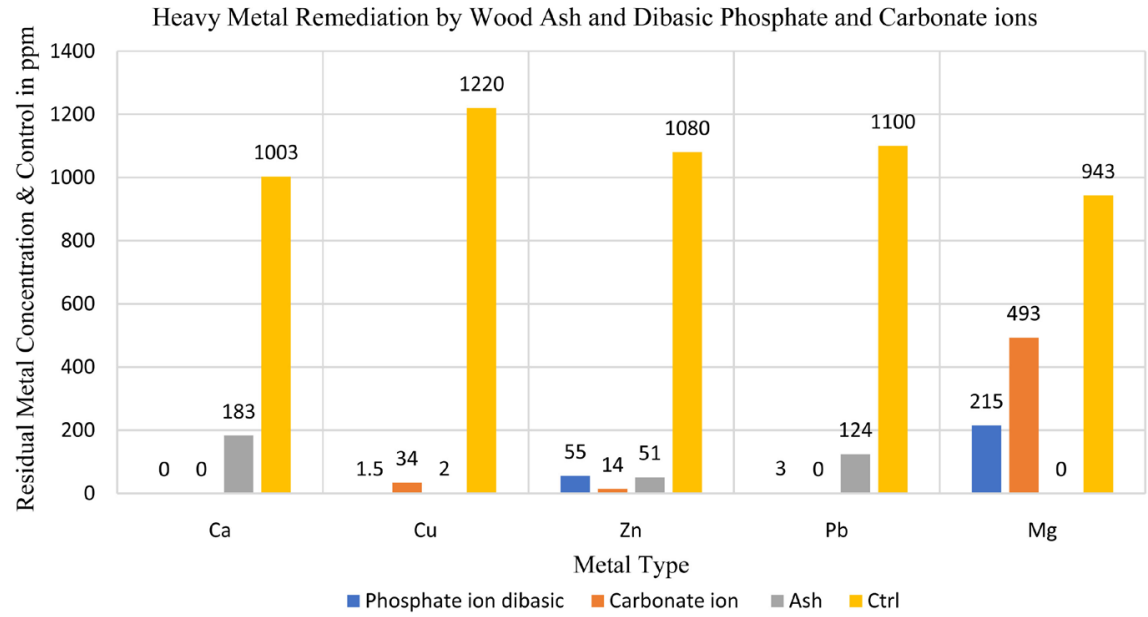

Figure 1. Residual metal concentration after treatment with Bi-phosphate ion, Carbonate ions, \& Wood ash.

Table 1. Percent removal of $\mathrm{Ca}, \mathrm{Cu}, \mathrm{Zn}, \mathrm{Pb}$ and $\mathrm{Mg}$ from contaminated water by the adsorbents.

\begin{tabular}{cccccc}
\hline ADSORBENTS & {$[\mathrm{Ca}]$} & {$[\mathrm{Cu}]$} & {$[\mathrm{Zn}]$} & {$[\mathrm{Pb}]$} & {$[\mathrm{Mg}]$} \\
\hline $\mathbf{H P O}_{4}^{2-}$ & 100 & 99.9 & 95 & 99.7 & 77 \\
$\mathbf{C O}_{3}^{2-}$ & 100 & $97 \%$ & 98.7 & 90.9 & 47.7 \\
$\mathrm{ASH}$ & 82 & 99.8 & 95 & 88.7 & 100 \\
\hline
\end{tabular}


lead > zinc > magnesium); for carbonate (calcium $>$ lead $>$ zinc $>$ copper $>$ magnesium); for wood ash (magnesium $>$ copper $>$ zinc $>$ lead $>$ calcium).

\section{Discussion}

Figure 1 and Table 1 clearly demonstrate a variation in metal removal. This variation could in part be due to differences in the properties of the metals and adsorbents. The Carbonate adsorbent was less effective in removing magnesium due to moderate molar solubility of the magnesium carbonate complex formed $\left(\mathrm{ksp} 6.82 \times 10^{-6}\right)$. The complex formed by sodium hydrogen phosphate with magnesium undergoes hydrogen bonding with the contaminated aqueous solution, thereby increasing the solubility of the complex formed. Wood ash effectively removed $100 \%$ of the magnesium in solution because the adsorbent may contain multiple functional groups that have strong binding affinity to the metal [30].

Figure 2 below from a separate experiment illustrates the comparison of metal removal by agricultural waste and carbonate ion. The data showed that agricultural waste (wood ash) was more efficient in removing lead, zinc and copper but not calcium. This may be due to the possible presence of calcium in wood ash [30] as reported by Risse and Gaskin [31]. It is also worthy to note that both adsorbents removed at least $96 \%$ of the metal pollutants from the contaminated aqueous solutions.

In another set of experiments, the efficiency of metal removal by tribasic and dibasic phosphate ions was compared as shown in Figure 3 below. The results suggest that both sodium phosphate tribasic $\left(\mathrm{Na}_{3} \mathrm{PO}_{4}\right)$ and sodium hydrogen phosphate dibasic $\left(\mathrm{Na}_{2} \mathrm{HPO}_{4}\right)$ were equally efficient in removing all the calcium

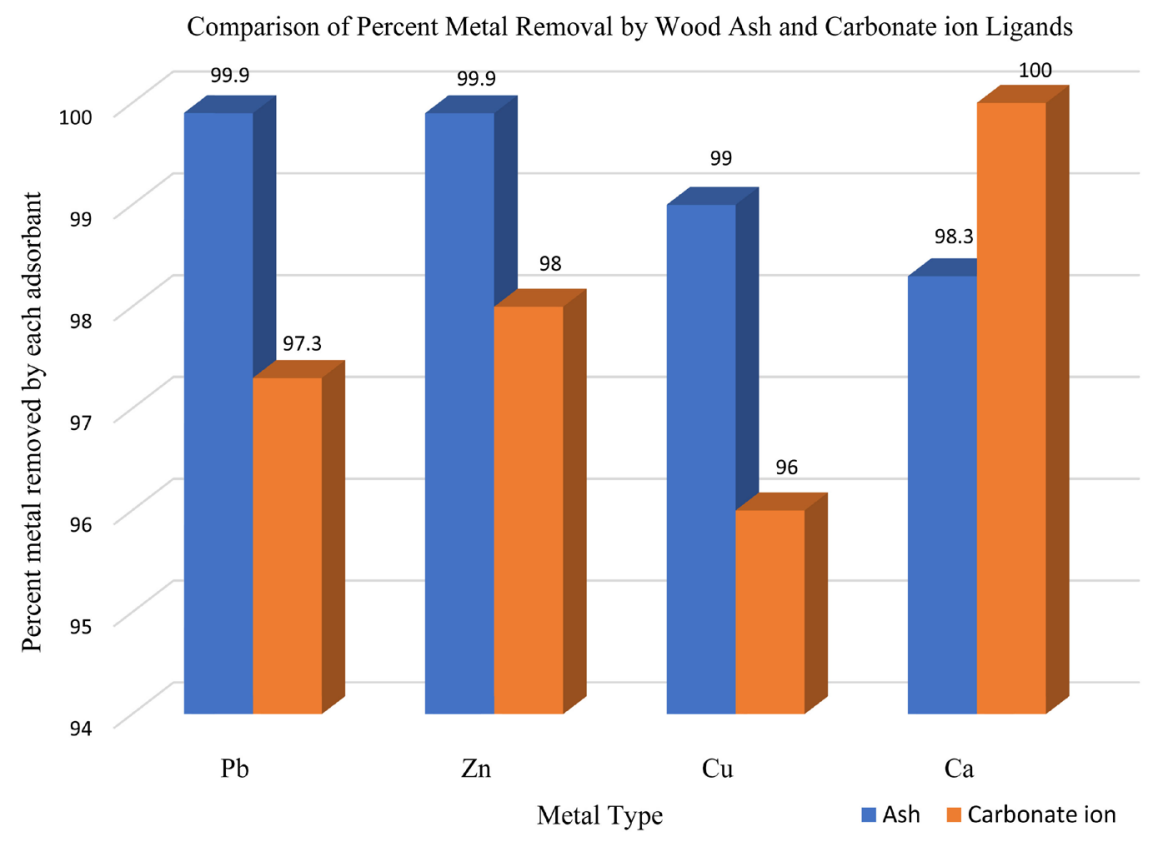

Figure 2. Comparison of metal removal by agricultural waste and carbonate ion. 


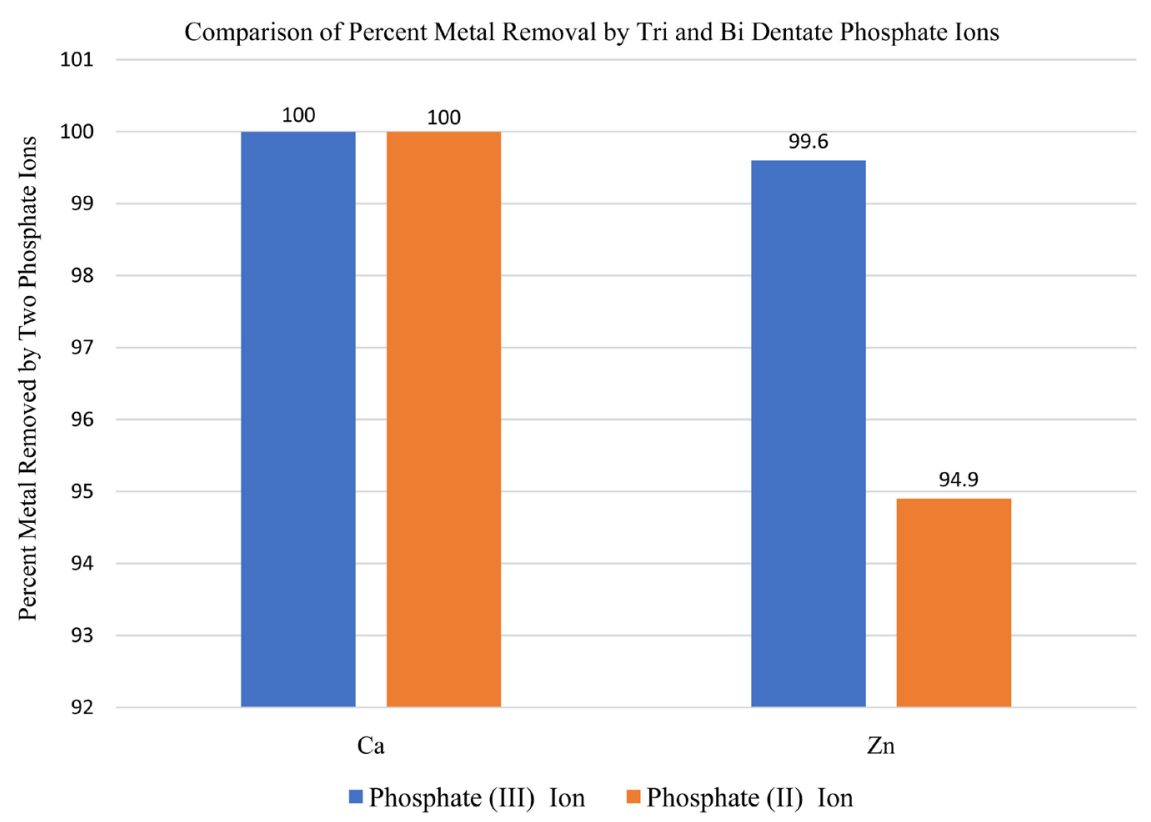

Figure 3. Comparison of calcium and Zinc removal by $\mathrm{Na}_{3} \mathrm{PO}_{4}$ and $\mathrm{Na}_{2} \mathrm{HPO}_{4}$.

from the contaminated aqueous solution. However, the tribasic phosphate ion was more efficient in removing zinc than the dibasic phosphate ion. This could be attributed to the possibility of acidic hydrogen in hydrogen phosphate participates in hydrogen bonding with the aqueous solution. Such hydrogen bonding can reduce the binding affinity of the phosphate to the zinc and increase the solubility of the formed Metal- $\mathrm{HPO}_{4}$ complex. Furthermore, tribasic phosphate has a greater number of binding sites (ligands) than dibasic phosphate. Additionally, the ionic radius of calcium is larger than that of zinc, therefore, the zinc can undergo intra particular diffusion into the pores of the adsorbent but could be forced out into the solution during centrifugation.

\section{Conclusion}

Although there exist a variety of research studies on the use of agricultural waste in removing metals from contaminated aqueous solutions, many of them were based on very dilute metal concentrations and high adsorbent/contaminated water ratio [32]. The research reported in this paper examined the use of wood ash to remove metals from $1000 \mathrm{ppm}$ contaminated aqueous solutions. Furthermore, very few studies have examined calcium and magnesium removal from contaminated water. The data on the comparison of metal removal by agricultural waste (wood ash) and inorganic chemical carbonate demonstrated that wood ash is equally if not more effective in removing metals than chemical carbonate. It is also worthy to note that for the metals studied, both the tribasic and dibasic phosphate ions remove the metals with nearly equal efficiency. Finally, the overall result showed that metal and adsorbent types affected the extent of metal removal. The order of metal removal by the adsorbents is: dibasic phosphate ( $\mathrm{Ca}>$ $\mathrm{Cu}>\mathrm{Pb}>\mathrm{Zn}>\mathrm{Mg})$; Dibasic Carbonate $(\mathrm{Pb} \sim \mathrm{Ca}>\mathrm{Zn}>\mathrm{Cu}>\mathrm{Mg})$; Wood Ash 
$(\mathrm{Mg}>\mathrm{Cu}>\mathrm{Zn}>\mathrm{Pb}>\mathrm{Ca})$. These results suggest that the inherent chemical properties of these metal cations may also contribute to their varying binding affinity to the ligand(s) in the adsorbents. On average across all metals, the order of metal removal by adsorbents is dibasic phosphate $>$ wood ash $>$ dibasic carbonate.

\section{Acknowledgements}

The authors would like to thank Ben Onye, Tiara Hamilton, Mya Bush and Dillard University Office of Academic Affairs for research supplies.

\section{Conflicts of Interest}

The authors declare no conflicts of interest regarding the publication of this paper.

\section{References}

[1] Kapahi, M. and Sachdeva, S. (2019) Bioremediation Options for Heavy Metal Pollution. Journal of Health and Pollution, 9, Article ID: 191203. https://doi.org/10.5696/2156-9614-9.24.191203

[2] Ziarati, P., Asgarpanah, J. and Makki, F.M. (2015) Phytoremediation of Heavy Metal Contaminated Water Using Potential Caspian Sea Wetland Plant: Nymphaeaceae. Biosciences Biotechnology Research Asia, 12, 2467-2473. https://doi.org/10.13005/bbra/1925

[3] Taiwo, I. and Osunkiyesi, B. (2015) Phytoremediation of Heavy Metals (Cu, Zn, and $\mathrm{Pb}$ ) Contaminated Water Using Water Hyacinth (Eichornia crassipes). IOSR Journal of Applied Chemistry, 8, 65-72.

[4] Shawai, S.A.A., Muktar, H.I., Bataiya, A.G., Abdullahi, I.I., Shamsuddin, I.M., Yahaya, A.S. and Suleiman, M. (2017) A Review on Heavy Metals Contamination in Water and Soil: Effects, Sources and Phytoremediation Techniques. International Journal of Mineral Processing and Extractive Metallurgy, 2, 21-27. https://doi.org/10.11648/j.ijmpem.20170202.12

[5] Jin, W. and Zhang, Y. (2020) Sustainable Electrochemical Extraction of Metal Resources from Waste Streams: From Removal to Recovery. ACS Sustainable Chemistry \& Engineering, 8, 4693-4707. https://doi.org/10.1021/acssuschemeng.9b07007

[6] Alawan, H.A., Kadhom, M. and Alminshid, A.H. (2020) Removal of Heavy Metals from Wastewater Using Agricultural Byproducts. Journal of Water Supply: Research and Technology-Aqua, 69, 99-112. https://doi.org/10.2166/aqua.2020.133

[7] Sud, D., Mahajan, G. and Kaur, M.P. (2008) Agricultural Waste Material as Potential Adsorbent for Sequestering Heavy Metal Ions from Aqueous Solutions-A Review. Bioreseource Technology, 99, 6017-6027. https://doi.org/10.1016/j.biortech.2007.11.064

[8] Agwaramgbo, L.O.E., Zulpo, S. and Lira, S.O. (2017) Competitive Adsorption of $\mathrm{Cu}(\mathrm{II})$ and $\mathrm{Zn}$ (II) from Binary Heavy Metal Solutions by Coffee Waste. Current Journal of Applied Science and Technology, 19, 1-9. https://doi.org/10.9734/BJAST/2017/31336

[9] Agwaramgbo, L., Lathan, N., Thomas, C. and Edwards, S. (2013) Comparative Study of Lead Removal by Extracts of Spinach, Coffee, and Tea. Journal of Environmental Protection Agency, 4, 250-257. http://doi.org/10.4236/jep.2013.43029 
[10] Agwaramgbo, L., Magee, N., Nunez, S. and Mitt, K. (2013) Biosorption and Chemical Precipitation of Lead Using Biomaterials, Molecular Sieve, and Chlorides, Carbonates, and Sulfates of $\mathrm{Na} \& \mathrm{Ca}$. Journal of Environmental Protection, 4, 1251-1257. https://doi.org/10.4236/jep.2013.411145

[11] Singh, R.G., Mishra, N.A. and Gupta, R. (2011) Heavy Metals and Living Systems: An Overview. Indian Journal of Pharmacology, 43, 246-253.

https://doi.org/10.4103/0253-7613.81505

[12] Banum, S.J. (1982) Introduction to Organic and Biological Chemistry. 3rd Edition, MacMillan, New York.

[13] Truong-Tran, A.Q., Carter, J., Ruffin, R.E. and Zalewski, P.D. (2001) The Role of Zinc in Caspase Activation and Apoptotic Cell Death. BioMetals, 14, 315-330. https://doi.org/10.1023/a:1012993017026

[14] Manzoor, Q., Nadeem, R., Iqbal, M., Saeed, R. and Ansari, TM. (2013) Organic Acids Pre-Treatment Effect on Rosa bourbonia Phyto-Biomass for Removal of $\mathrm{Pb}$ (II) and $\mathrm{Cu}$ (II) from Aqueous Media. Bioresource Technology, 132, 446-452. https://doi.org/10.1016/j.biortech.2013.01.156

[15] Uriu-Adams, J.Y. and Keen, C.L. (2005) Copper, Oxidative Stress and Human Health. Molecular Aspects of Medicine, 26, 268-298. https://doi.org/10.1016/j.mam.2005.07.015

[16] Pandit, A. and Bhave, S. (1996) Present Interpretation of the Role of Copper in Indian Childhood Cirrhosis. American Journal of Clinical Nutrition, 63, 830S-835S. https://doi.org/10.1093/ajcn/63.5.830

[17] Muller, T., Feichtinger, H., Berger, H. and Muller, W. (1996) Endemic Tyrolean Cirrhosis: An Ecogenetic Disorder. Lancet, 347, 877-880.

https://doi.org/10.1016/s0140-6736(96)91351-3

[18] Scheinberg, I.H. and Sternlieb, I. (1994) Is Non-Indian Childhood Cirrhosis Caused by Excess Dietary Copper. Lancet, 344, 1002-1004. https://doi.org/10.1016/S0140-6736(94)91649-7

[19] Plum, L.M., Rink, L. and Haase, H.L. (2010) The Essential Toxin: Impact of Zinc on Human Health. International Journal of Environmental Research and Public Health, 7, 1342-1365. https://doi.org/10.3390/ijerph7041342

[20] Brown, M.A., Thom, J.V., Orth, G.L., Cova, P. and Juarez, J. (1964) Food Poisoning Involving Zinc Contamination. Archives of Environmental Health, 8, 657-660. https://doi.org/10.1080/00039896.1964.10663736

[21] Cummings, J.E. and Kovacic, J.P. (2009) The Ubiquitous Role of Zinc in Health and Disease. Journal of Veterinary Emergency and Critical Care, 19, 215-240.

https://doi.org/10.1111/j.1476-4431.2009.00418.x

[22] Edwards, M., Triantafyllidis, S. and Best, D. (2009) Elevated Blood Lead in Young Children Due to Lead-Contaminated Drinking Water: Washington, D.C., 2001-2004. Environmental Science \& Technology, 43, 1618-1623.

https://doi.org/10.1021/es802789w

[23] Brown, M.J., Raymond, J., Homa, D., Kennedy, C. and Sinks, T. (2011) Association between Children's Blood Lead Levels, Lead Service Lines, and Water Disinfection, Washington, DC, 1998-2006. Environmental Research, 111, 67-74. https://doi.org/10.1016/j.envres.2010.10.003

[24] Triantafyllidis, S. and Edwards, M. (2011) Lead (Pb) in Tap Water and in Blood: Implications for Lead Exposure in the United States. Critical Reviews in Environmental Science and Technology, 42, 1297-1352. https://doi.org/10.1080/10643389.2011.556556 
[25] Borja-Aburto, V.J., Hertz-Picciotto, I., Lopez, M.R., Farias, P., Rios, C. and Blanco, J. (1999) Blood Lead Levels Measured Prospectively and Risk of Spontaneous Abortion. American Journal of Epidemiology, 105, 590-597.

https://doi.org/10.1093/oxfordjournals.aje.a010057

[26] Troesken, W. (2008) Lead Water Pipes and Infant Mortality at the Turn of the Twentieth Century. Journal of Human Resources, 43, 553-575. https://doi.org/10.3368/jhr.43.3.553

[27] Edwards, M. (2014) Fetal Death and Reduced Birth Rates Associated with Exposure Lead-Contaminated Drinking Water. Environmental Science \& Technology, 48, 739746. https://doi.org/10.1021/es4034952

[28] Musa, A., Yakasai, L.A. and Ya'u, I.B. (2008) The Concentrations of Lead in Shallow Well, Borehole and Package Water Samples in Zaria, Nigeria. International Journal of Pure and Applied Sciences, 2, 22-27.

[29] Kaplan, S. and Hiar, C. (2012) How an EPA Project Backfired, Endangering Drinking Water with Lead. NBC News Investigative, 8 August 2012.

[30] Agwaramgbo, L.O.E., Cardoso, R.F. and Matos, T.S. (2016) Copper and Zinc Removal from Contaminated Water Using Coffee Waste. Journal of Scientific Research and Reports, 12, 1-9. https://doi.org/10.9734/JSRR/2016/31118

[31] Risse, M. and Gaskin, J. (2010) Best Management Practices for Wood Ash as Agricultural Soil Amendment. Bulletin 1142, UGA Cooperative Extension, Athens.

[32] Malakootian, M., Yaghmaeian, K. and Malakootian, M. (2006) Wood Ash Effectiveness in Cadmium Removal from Paint Industrial Effluent. Pakistan Journal of Biological Sciences, 9, 248-252. https://doi.org/10.3923/pjbs.2006.248.252 